\title{
Pathogenic complexity of septoria spot disease of wheat in northern Kazakhstan
} \author{
Pakholkova $^{2}$ \& Belgibay Kamalovich Kanafin ${ }^{3}$ \\ ${ }^{1}$ LLP, Scientific-Production Center of Grain Farming named after A.I. Barayev, Kazakhstan \\ ${ }^{2}$ All-Russian Research Institute of Phytopathology, Russia \\ ${ }^{3}$ LLP, North Kazakhstan Agricultural Experimental Station, Kazakhstan \\ *Email: sbabkenova@mail.ru
}

Sandukash Amantaevna Babkenova ${ }^{1 *}$, Adylkhan Temirhanovich Babkenov ${ }^{1}$, Elena Vasilyevna

\section{ARTICLE HISTORY}

Received: 16 April 2020

Accepted: 26 September 2020

Published: 01 October 2020

\section{KEYWORDS}

Spring common wheat

Stagonospora nodorum

Septoria tritici

Stagonospora avenae f.sp. Triticea

species diversity

\begin{abstract}
Northern Kazakhstan is the main zone of spring wheat cultivation where, $85 \%$ of the cultivated area is located. There is not a single variety resistant to Septoria spot among the varieties approved for use. The frequency of epiphytoties of wheat diseases in the northern part of Kazakhstan is four cases every ten years. During the years of epiphytotic development of brown rust and Septoria spot with the dominance of a particular disease, the yield of spring wheat is reduced by $25 \%$ or more. Knowledge of the species composition of pathogens of Septoria spot allows a more focused approach to the study and creation of varieties of wheat resistant to this disease. The aim of the research is to study the species of Septoria spot pathogens in wheat in Northern Kazakhstan. In 2018-2019, the pathogenic complex of the causative agents of wheat Septoria spot was studied. The collection of leaves affected by Septoria spot was carried out on spring wheat varieties in the steppe, forest-steppe zones of Northern Kazakhstan. The species composition of Septoria pathogens was determined from microscopic preparations from the collected samples; which were represented by three types of septorial fungi: Septoria tritici, Stagonospora nodorum, Stagonospora avenae. In the steppe and foreststeppe zones of Northern Kazakhstan, the dominant species was S. tritici followed by S. nodorum.
\end{abstract}

\section{Introduction}

Annually, on average, about 13.0 million tons of grain are produced in Kazakhstan (1). The average grain yield is 1.1 tons per hectare. There is a large number of harmful fungal diseases of wheat, and Septoria spot is currently the dominant one. Septoria tritici and Stagonospora nodorum cause significant crop loss and severely reduce grain quality $(2,3)$. Epiphytoties of various diseases had been observed on the wheat crops four times in the last ten years. Annual yield losses amount to 10-15\% in cases of moderate development of the disease and up to $40 \%$ during epiphytoties (4-6). Grain yield losses occur mainly as a result of a decrease in ear grain content and grain weight in diseased plants (7-10). The study of the species diversity of pathogens of Septoria allows identifying their most common types in the region.
The aim of the research was to study the species composition of the pathogens of wheat Septoria spot in Northern Kazakhstan.

\section{Materials and Methods}

The study of the species composition of the populations of Septoria spot pathogens in a specific area began with examinations of spring common wheat crops, the names of which are given in Table 1. These varieties were sown with SZS-2.1 stubble seeder in the optimal time from 20-25 May in 2018-2019. To obtain a reliable picture of the spread of the disease, we examined the steppe zone of the Akkayin, Esil districts, as well as the forest-steppe zone of the Mamlyut and Kyzylzhar districts of Northern Kazakhstan (Fig. 1).

(c) Babkenova et al (2020). This is an open-access article distributed under the terms of the Creative Commons Attribution License, which permits unrestricted use, distribution and reproduction in any medium, provided the original author and source are credited (https://creativecommons.org/licenses/by/4.0/)

To cite this article: Babkenova S A, Babkenov A T, Pakholkova E V, Kanafin B K. Pathogenic complexity of septoria spot disease of wheat in northern Kazakhstan. Plant Science Today. 2020;7(4):601-606. https://doi.org/10.14719/pst.2020.7.4.798 


\section{Natural agricultural areas of Northern Kazakhstan}

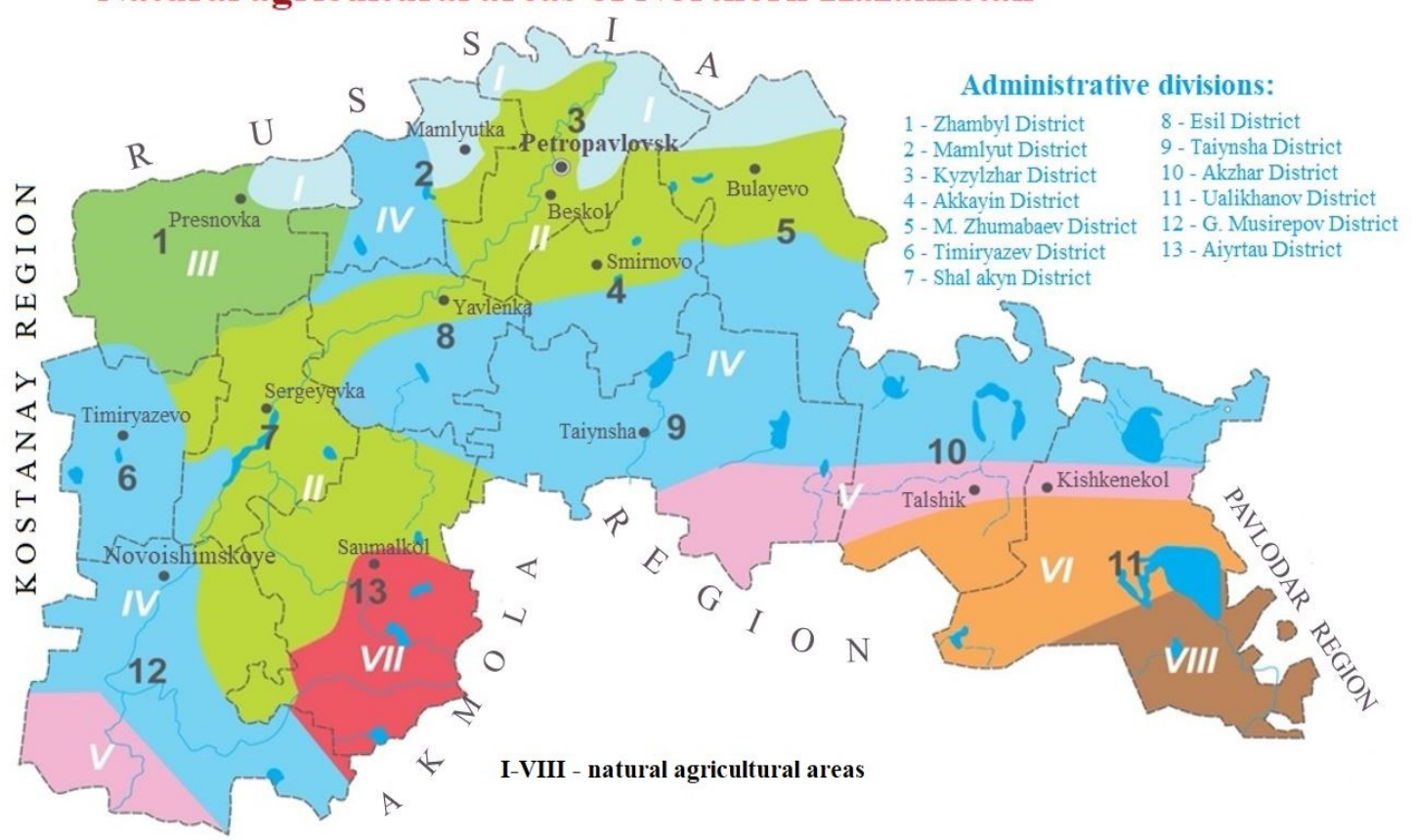

Fig.1. Map of the studied areas of the Northern Kazakhstan.

The accounting for Septoria infection was determined according to the international James' scale (11). The collected material was put into bags, properly labelled indicating the place, date of collection, phase of plant development, variety name, the date and method of sowing, the degree of damage to the plants, which was determined as the average percentage of the affected leaf surface. The bags were later stored in the refrigerator at a temperature of +5$8^{\circ} \mathrm{C}(12)$.

To determine the species composition of Septoria spot pathogens, microscopic preparations were made from the collected samples. Pieces of the affected tissue were placed on a glass slide in a drop of water for several minutes, and the preparation was examined under a microscope (Leica DFS 320) at 20$40 \mathrm{x}$ magnification. The species of the fungus were identified using field guides based on the shape and size of pycnospores (13).

\section{Results}

Weather conditions in 2018, namely rainfall in the end of June and throughout the month of July, heavy rains in August contributed to the development and spread of Septoria spot. The degree of damage during the phase of milky-wax ripeness reached $40-60 \%$. In 2019, the meteorological conditions of the spring wheat vegetation period were characterized as arid. Precipitation in June, July and August totalled $82 \mathrm{~mm}$, which was by $54.3 \mathrm{~mm}$ lower than the average longterm norm. The spread of the disease reached $100 \%$, and the development was weak (up to $14 \%$ ).

In 2018, the spread of Septoria spot on wheat crops was monitored in the forest-steppe zone of the Mamlyutsky, Kyzylzhar districts and in the steppe zone of Akkayin, Esil districts of Northern Kazakhstan.
Based on mycological analysis, in the steppe zone of Northern Kazakhstan, in spring wheat varieties, $S$. nodorum, $S$. tritici and $S$. avenae f. sp. triticea were determined (Fig. 2-5). By frequency of occurrence, $S$. tritici prevailed everywhere, with the exception of the "Atameken-Agro-Korneevka" LLP farm in the Esil district. S. avenae f. sp. triticea (96.7 $\%)$ prevailed at this farm, with $S$. nodorum (43.3\%) being the second most frequent species and $S$. tritici $(6.7 \%)$ being the third. In other farms, the average incidence rate of $S$. tritici was $64,7 \%$. The rates for species $S$. nodorum and $S$. avenae f. sp. triticea were lower; the average incidence of $S$. nodorum was 30.7 $\%$ and the average incidence of $S$. avenae f. sp. triticea was $25.3 \%$ (Table 1 ).

Mycological study in the forest-steppe zone showed that Septoria tritici dominated in the spring wheat varieties. Its incidence reached up to $100 \%$ at the "Gadzhiev" farm household in the Mamlyut district. The average incidence for this species was $75.0 \%$. The average incidence of $S$. nodorum in wheat varieties was $11.5 \%$. S. avenae f. sp. triticea had an average incidence of $0.8 \%$ and was recorded only at the "Gadzhiev" farm household in the Mamlyutsky district.

According to the results of the mycological analysis in 2018, it was found that Septoria tritici $(69.9 \%)$ was predominant in two zones, S. nodorum (21.1\%) was second, and the lowest average incidence was observed for $S$. avenae f. sp. triticea (13.1\%).

According to the results of the mycological analysis in 2019 in the steppe zone, $S$. tritici prevailed in spring wheat varieties. In several cases, for example, in the Astana variety, $S$. nodorum prevailed. The average incidence of $S$. tritici in the Akkayin and Esil districts was $25.3 \%$. S. nodorum and S. avenae f. 


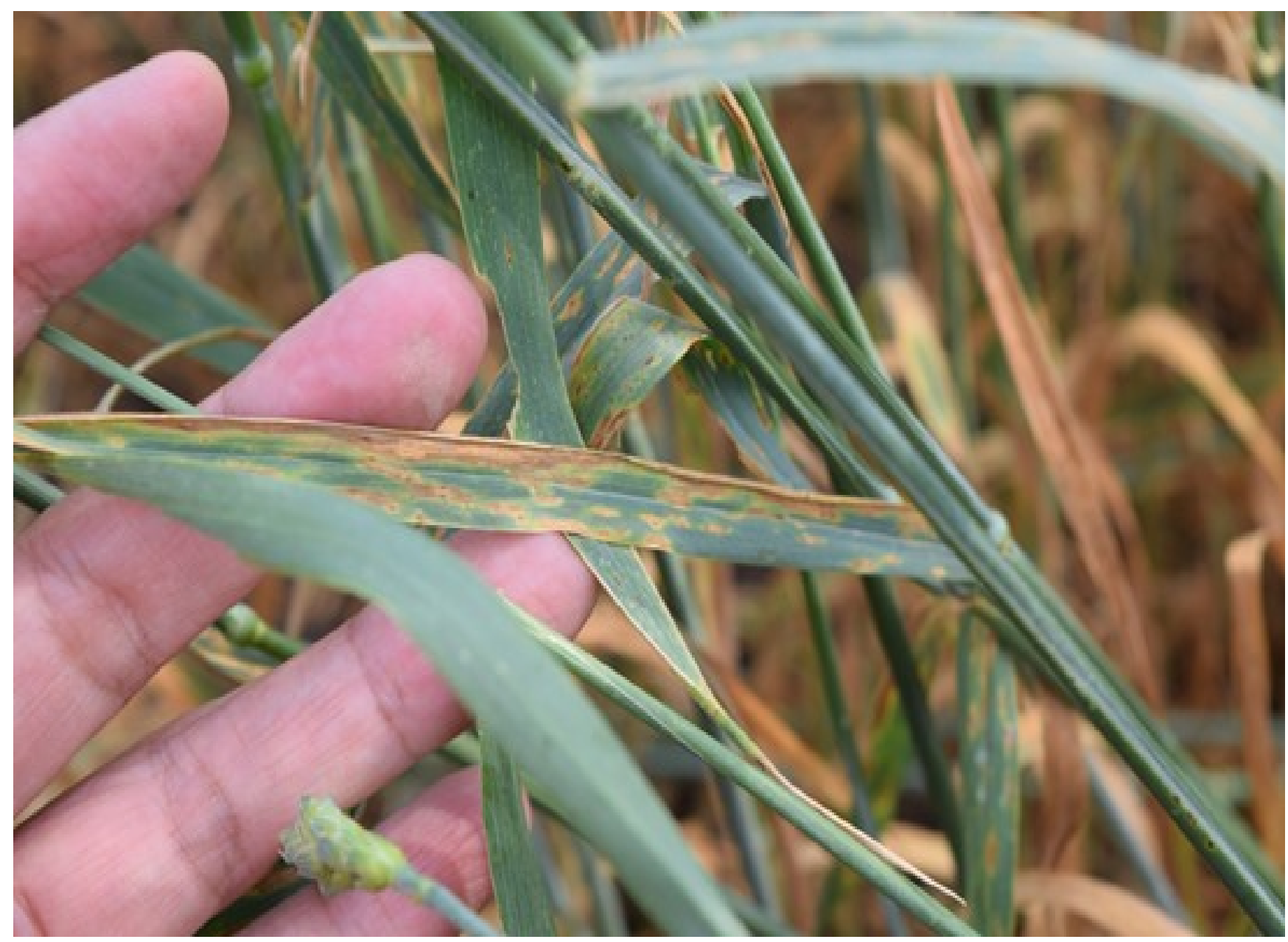

Fig. 2. Wheat leaves affected by Septoria spot.

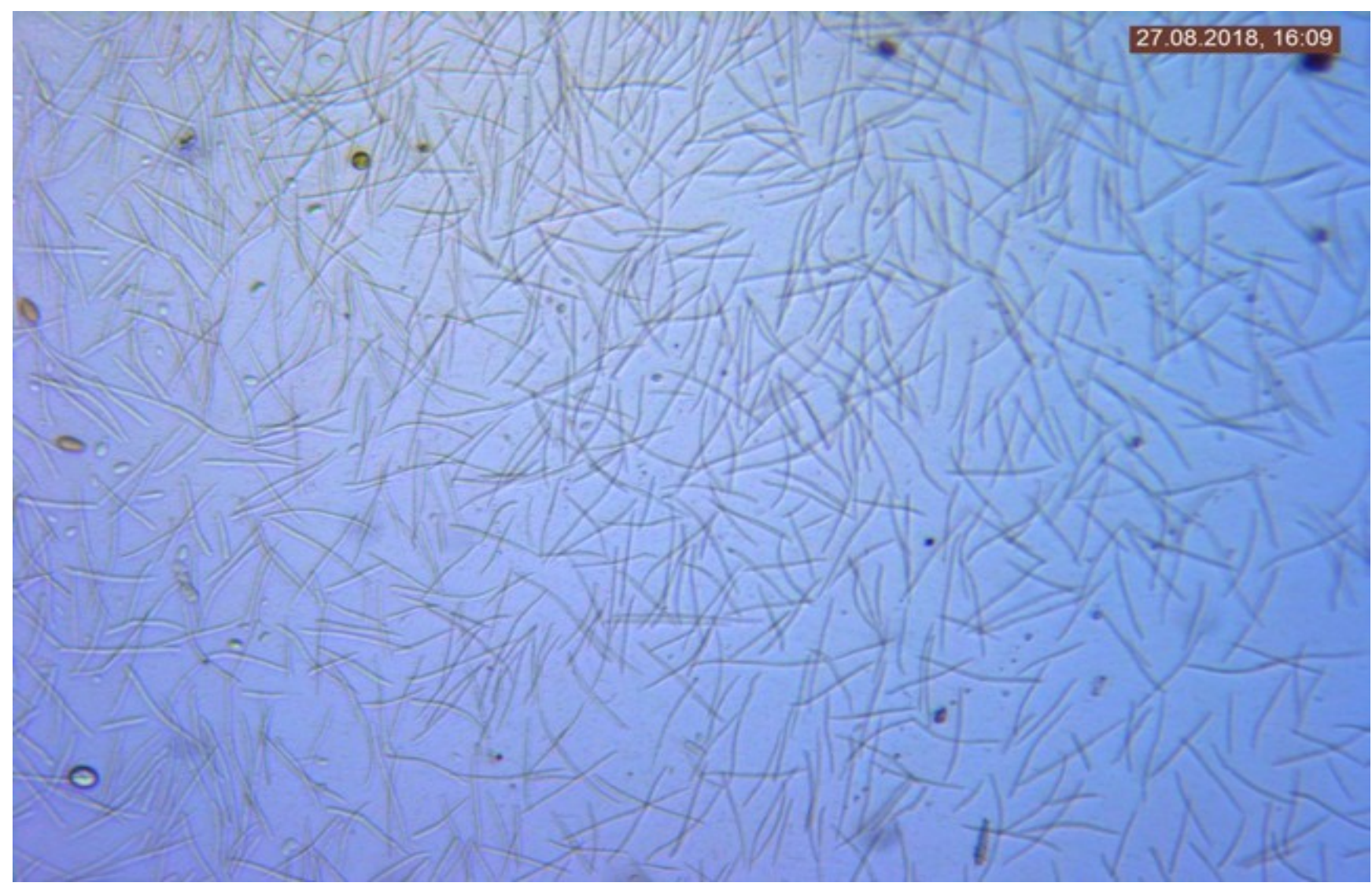

Fig. 3. Spores of S. tritici on Shortandy 95 improved variety. 


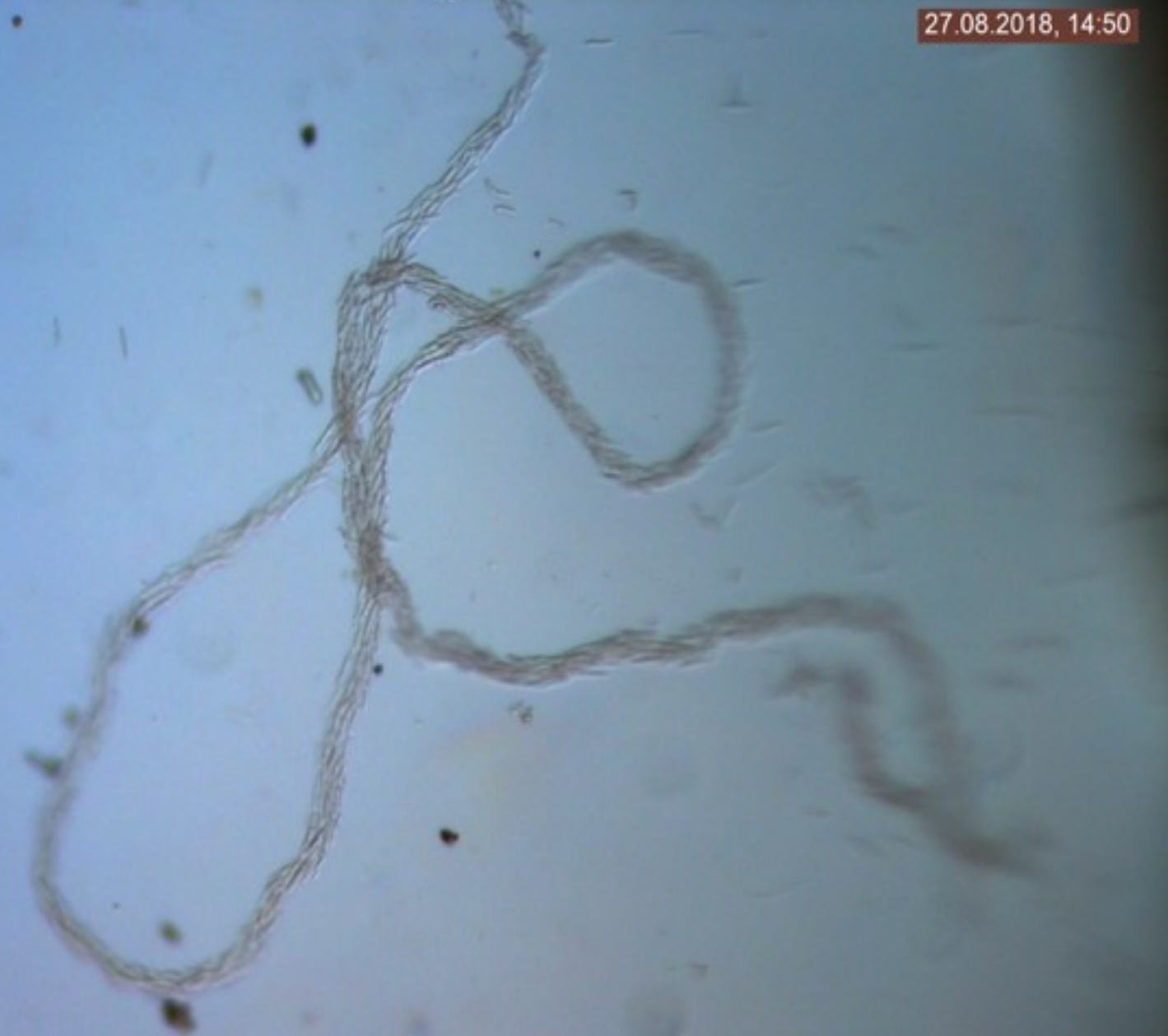

Fig. 4. Spores of $S$. nodorum on Omsk 35 variety.

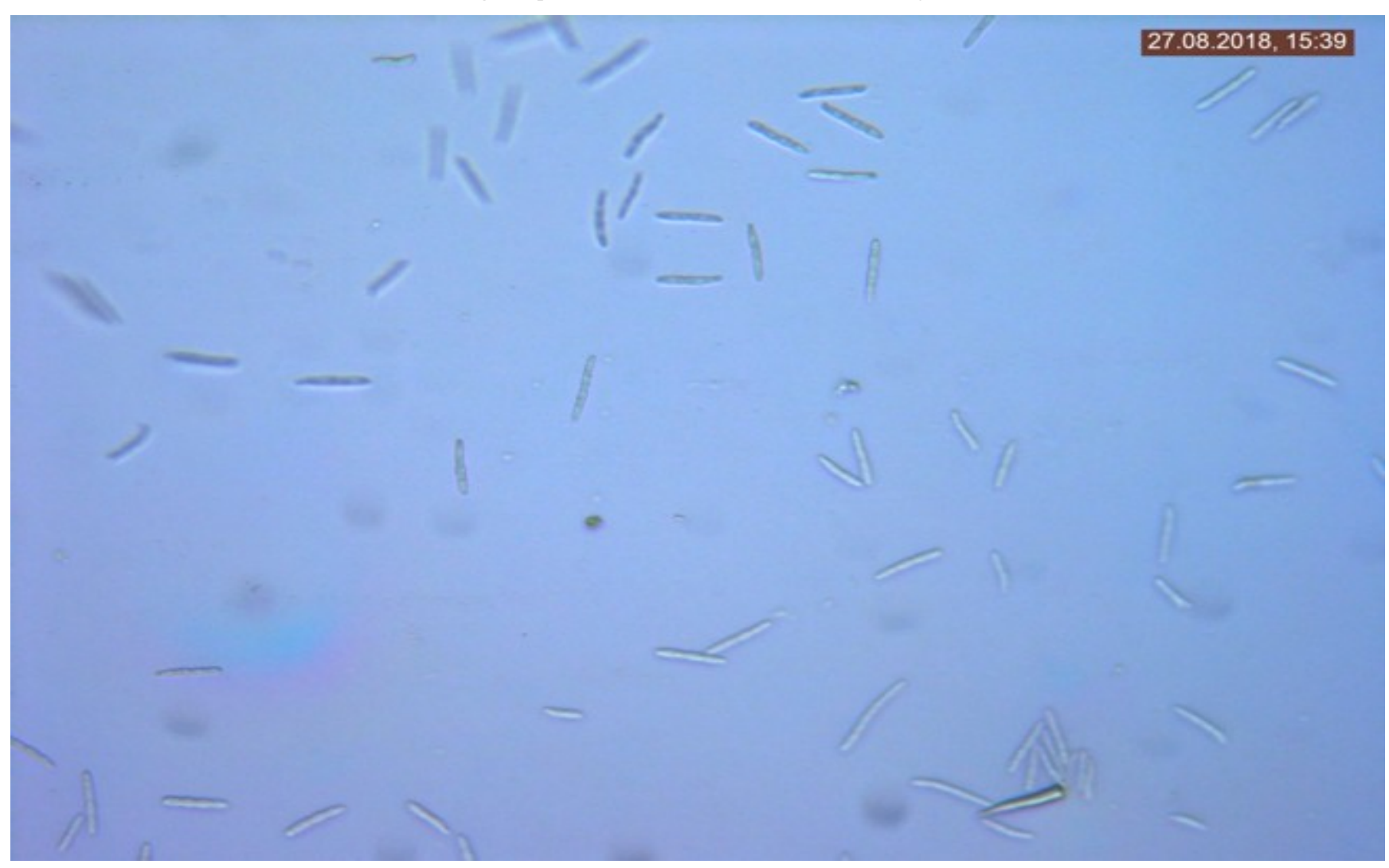

Fig. 5. Spores of S. avenae f.sp. triticea on Shortandy 95 improved variety. 
Table 1. The incidence of Septoria sp. in wheat in the steppe and forest-steppe zones of Northern Kazakhstan (2018)

\begin{tabular}{|c|c|c|c|c|c|}
\hline \multirow[b]{2}{*}{ Variety } & \multirow[b]{2}{*}{ District } & \multirow[b]{2}{*}{ Farm name } & \multicolumn{3}{|c|}{ Septoria sp., \% } \\
\hline & & & S. tritici & S. nodorum & $\begin{array}{c}\text { S. avenae f.sp. } \\
\text { triticea }\end{array}$ \\
\hline \multicolumn{6}{|c|}{ Steppe zone } \\
\hline Omsk 35 & Akkayin & “North Kazakhstan SOS” LLP & $63.3 \pm 2.2$ & $66.7 \pm 3.5$ & $10.0 \pm 1.1$ \\
\hline Tawelsizdik, 20 & Akkayin & "North Kazakhstan SOS” LLP & $86.7 \pm 3.0$ & $10.0 \pm 0.9$ & - \\
\hline Shortandy 95 improved & Akkayin & “North Kazakhstan SOS” LLP & $76.7 \pm 4.2$ & $13.3 \pm 1.0$ & - \\
\hline Astana & Akkayin & "Fiat” LLP & $90.0 \pm 9.5$ & $20.0 \pm 2.5$ & $20.0 \pm 2.8$ \\
\hline Shortandy 95 improved & Esil & “Atameken-Agro-Korneevka” LLP & $6.7 \pm 0.8$ & $43.3 \pm 5.1$ & $96.7 \pm 9.3$ \\
\hline \multicolumn{3}{|c|}{ Average } & $64.7 \pm 3.9$ & $30.7 \pm 2.6$ & $25.3 \pm 2.7$ \\
\hline \multicolumn{6}{|c|}{ Forest-steppe zone } \\
\hline Omsk 28 & Mamlyut & “Gadzhiev” farm household & $100.0 \pm 9.1$ & $10.0 \pm 1.5$ & $3.3 \pm 0.5$ \\
\hline Boevchanka & Mamlyut & “Amanzhelev” farm household & $80.0 \pm 10.1$ & $13.3 \pm 2.0$ & - \\
\hline Boevchanka & Mamlyut & “Tazhiev” LLP & $46.7 \pm 4.1$ & $10.1 \pm 1.8$ & - \\
\hline Novosibirsk 31 & Kyzylzhar & “Zenchenko” farm household & $73.3 \pm 8.8$ & $12.4 \pm 1.9$ & - \\
\hline \multicolumn{3}{|c|}{ Average } & $75.0 \pm 8.0$ & $11.5 \pm 1.8$ & $0.8 \pm 0.1$ \\
\hline
\end{tabular}

Table 2. The incidence of Septoria sp. in wheat in the steppe and forest-steppe zones of Northern Kazakhstan (2019)

\begin{tabular}{|c|c|c|c|c|c|}
\hline \multirow[b]{2}{*}{ Variety } & \multirow[b]{2}{*}{ District } & \multirow[b]{2}{*}{ Farm name } & \multicolumn{3}{|c|}{ Septoria sp., \% } \\
\hline & & & S. tritici & S. nodorum & $\begin{array}{c}\text { S. avenae f.sp. } \\
\text { triticea }\end{array}$ \\
\hline \multicolumn{6}{|c|}{ Steppe zone } \\
\hline Shortandy 95 improved & Akkayin & “North Kazakhstan SOS” LLP & $20.0 \pm 3.1$ & $3.3 \pm 0.7$ & $23.3 \pm 2.5$ \\
\hline Tawelsizdik 20 & Akkayin & “North Kazakhstan SOS” LLP & $10.0 \pm 2.1$ & - & - \\
\hline Omsk 35 & Akkayin & “North Kazakhstan SOS” LLP & $23.0 \pm 3.1$ & - & $20.0 \pm 2.8$ \\
\hline Astana & Akkayin & “Fiat” LLP & - & $53.3 \pm 4.5$ & $36.7 \pm 5.1$ \\
\hline Shortandy 95 & Esil & “Atameken-Agro- Korneevka” LLP & $73.3 \pm 7.8$ & $30.1 \pm 2.7$ & - \\
\hline \multicolumn{3}{|c|}{ Average } & $25.3 \pm 8.1$ & $17.3 \pm 2.0$ & $16.0 \pm 2.1$ \\
\hline \multicolumn{6}{|c|}{ Forest-steppe zone } \\
\hline Omsk 28 & Mamlyut & “Gadzhiev” farm household & $40.0 \pm 5.5$ & - & - \\
\hline Boevchanka & Mamlyut & “Amanzhelev” farm household & - & $80.0 \pm 7.1$ & $43.3 \pm 3.8$ \\
\hline Boevchanka & Mamlyut & “Tazhiev” LLP & $6.7 \pm 1.1$ & $43.3 \pm 5.1$ & $6.7 \pm 0.5$ \\
\hline Novosibirsk 31 & Kyzylzhar & “Zenchenko” farm household & $86.7 \pm 9.2$ & $13.3 \pm 1.5$ & - \\
\hline \multicolumn{3}{|c|}{ Average } & $33.4 \pm 4.0$ & $34.2 \pm 3.4$ & $12.5 \pm 1.1$ \\
\hline
\end{tabular}

sp. triticea in had the same level of incidence; $17.3 \%$ and $16.0 \%$ respectively.

A mycological study of the affected leaves collected from 4 wheat varieties was carried out in the forest-steppe zone. $S$. tritici prevailed in two samples and $S$. nodorum prevailed in two samples. The average incidence values were as follows: $33.4 \%$ for $S$. tritici; $12.5 \%$ for $S$. avenae f. sp. triticea and $34.2 \%$ for $S$. nodorum.

According to the results of the 2019 surveys, it was found that $S$. tritici dominated in two zones, its average incidence was $29.4 \%$ in spring wheat varieties, $S$. avenae f. sp. triticea incidence was $14.3 \%$, and the proportion of $S$. nodorum was $25.8 \%$ (Table 2).

\section{Conclusion}

The species composition of pathogens populations of wheat Septoria spot in Northern Kazakhstan in 20182019 was comprised of three species of Septoria fungi: $S$. tritici, $S$. nodorum and $S$. avenae f. sp. triticea. Soft spring wheat was mainly affected by the $S$. tritici. During the two-year study of species diversity of Septoria spot pathogens, $S$. tritici was predominant followed by $S$. nodorum and $S$. avenae $\mathrm{f}$. sp. triticea.

\section{Authors' contributions}

All authors contributed to conduct the study and prepare the manuscript. The final version of the manuscript has been approved by all authors.

\section{Acknowledgements}

This study was performed as part of a grant funding programme of the Science Committee of the Ministry of Education and Science of the Republic of Kazakhstan for the project "The role of varieties that are stable and tolerant to Septoria spot and the use of the technologies of their cultivation in stabilizing the phytosanitary conditions of agrocenoses".

\section{Conflict of interests}

The authors declare no competing interests. 


\section{References}

1. Analiz otrasli rastenievodstva [Analysis of the crop industry]. Analiticheskaya sluzhba Reitingovogo agentstva RFTsA [Analytical service of the Almaty Regional Financial Centre Rating Agency]. Almaty; 2013, p. 4-5.

2. Eyal Z, Scharen AL, Prescott JM and Van Ginkel M. The Septoria diseases of wheat: concepts and methods of disease management. CIMMYT, Mexico, D.F.; 1987.

3. Singh PK, Duveiller E, Singh RP, Singh S, Herrera-Foessel SA, Huerta-Espino J, Manes Y, Bonnett D and Dreisigacker S. Characterization of CIMMYT germplasm for resistance to Septoria diseases of wheat. In: Duveiller E, Singh PK. (editors). Proceedings of the 8th International Symposium on Mycosphaerella and Stagonospora Diseases of Cereals; 2011 Sep 10-14; Mexico. Mexico City; 2011. 10-14.

4. Babkenova SA, Babkenov AT, Kolomiets TM, Skolotneva ES and Divashuk MG. Molecular genetic tagging of wheat varieties genes resistant to Septoria tritici in northern Kazakhstan. International Journal of Green Pharmacy [Internet]. 2017 [cited 2020 Feb 22];11(3):430-37.

5. Mergoum M, Singh PK, Ali S, Elias EM, Anderson JA, Glover KD and Adhikari TB. Reaction of Elite Wheat Genotypes from the Northern Great Plains of North America to Septoria Diseases. Plant Disease [Internet]. 2007 [cited 2020 Feb 22];91(10):131015. https://doi.org/10.1094/PDIS-91-10-1310

6. Ponomarenko A, Goodwin SB and Kema GHJ. Septoria tritici blotch (STB) of wheat. Plant Health Inst [Internet]. 2011 [cited 2020 Feb 22]. https://doi.org/10.1094/PHI-I-2011-0407-01

7. Zeleneva YuV, Sudnikova VP and Plakhotnik VV. Ustoichivost raionirovannykh sortov pshenitsy $\mathrm{k}$ epifitotiino opasnym boleznyam. [Resistance of zoned wheat varieties to epiphytotic dangerous diseases]. Vestnik TGU [Internet]. 2017 [cited 2020 Feb 22];2(22):404-410. https://doi.org/10.20310/1810-0198-201722-2-404-410

8. Plakhotnik VV, Zeleneva YuV and Sudnikova VP. Istochniki i vysokoeffektivnye donory dlya selektsii yarovoi pshenitsy na ustoichivost k stressovym faktoram sredy. [Sources and highly effective donors for breeding of spring wheat for resistance to environmental stress factors.]. Voprosy sovremennoi nauki i praktiki [Internet]. 2014 [cited 2020 Feb 22];1(50):109-13.

9. Sanin SS, Korneva LG, Polyakova TM and Akimova EA. Prognoz riskov razvitiya epifitotii septorioza listev i kolosa ozimoi i yarovoi pshenitsy. [Prognosis of the risks of development of epiphytotic Septoria leaf and ear blotch in winter and spring wheat]. Zashchita i karantin rastenil [Internet]. 2015 [cited 2020 Feb 22];3:33-6.

10. Jamali S. First report of Septoria silybi associated with leaf blotch of Silybum marianum from Iran. Plant Science Today [Internet]. 2015 [cited 2020 Jul 13];2(1):21-23. https://doi.org/10.14719/pst.2015.2.1.82

11. James WC. An illustrated series of assessment diseases preparation and usage. Canadian Plant Disease Survey [Internet]. 1971 [cited 2020 Aug 27];51:36-65.

12. Kolomiets TM, Pakholkova EV and Dubrovaya LP. Otbor iskhodnogo materiala dlya sozdaniya sortov pshenitsy s dlitel'noi ustoichivost'yu $\mathrm{k}$ septoriozu [Selection of source material for the creation of wheat varieties with long-term resistance to Septoria spot]. Moscow: Print City; 2017.

13. Pidoplichko NM. Fungi - parasites of cultivated crops. Vol. 2. Kiev: Naukova Dumka; 1977. 